\title{
透過型電子顕微鏡を用いたディーゼル噴霧火炎内すす粒子性状解析
}

\author{
近藤 克文 ${ }^{* 1}$, 山口 輝夫 ${ }^{* 2}$, 西貝 大樹 ${ }^{* 3}$ ，相澤 哲哉 ${ }^{* 4}$
}

\section{Transmission electron microscopy of soot directly sampled at different axial locations in diesel spray flame}

\author{
Katsufumi KONDO*1, Teruo YAMAGUCHI ${ }^{* 2}$, Hiroki NISHIGAI*3 ${ }^{*}$ and Tetsuya AIZAWA*4 \\ ${ }^{{ }_{1}, *_{2},{ }^{*} 3}$ Graduate School of Science and Technology, Meiji University \\ 1-1-1 Higashi-mita, Tama-ku, Kawasaki-shi, Kanagawa 214-8571, Japan \\ ${ }^{*}$ Department of Mechanical Engineering Informatics, Meiji University \\ 1-1-1 Higashi-mita, Tama-ku, Kawasaki-shi, Kanagawa 214-8571, Japan
}

\section{Received 24 June 2015}

\begin{abstract}
For further reduction of particulate emission from a diesel vehicle, it is fundamentally important to understand in-flame soot formation and oxidation processes. In order to clarify the processes, the morphology of soot directly sampled at different locations in the spray flame (40 $\mathrm{mm}$ to $90 \mathrm{~mm}$ from the injector nozzle tip) were investigated using a transmission electron microscope (TEM). The diesel spray flame was achieved in a constant volume combustion chamber under diesel-like conditions $(2.5 \mathrm{MPa}$ and $940 \mathrm{~K})$. The concentration, diameter of primary particles and the radius of gyration of soot aggregates increased in the upstream region (40 to $50 \mathrm{~mm}$ ), exhibited a peak around the mid-stream region $(60$ to $70 \mathrm{~mm})$, and then decreased in the downstream region $(80$ to $90 \mathrm{~mm}$ ), which corresponds to formation, peak concentration and oxidation of soot particles in the spray flame, respectively. The fractal dimension of soot aggregates was also analyzed and was almost constant, with a value of approximately 1.73 over different axial locations in the spray flame, which suggests that the dominant growth process of in-flame soot aggregate is cluster-cluster aggregation in diffusion limited regime.
\end{abstract}

Key words : Diesel engine, Diesel spray flame, TEM, Soot, PM, Morphology

\section{1. 緒言}

ディーゼル機関から排出される粒子状物質を極限まで低減するためには，すす粒子の生成及び酸化過程を詳細 に理解することが重要である。す寸粒子のサイズ，形態，微細構造は，すすの生成，成長及び酸化過程を反映す ると共に酸化速度に影響を与えることが知られている．透過型電子顕微鏡(TEM)観察は，これらのす寸粒子性状 及び微細構造を観察・理解するのに最も直接的で有効な手法の 1 つである。排気中のすす粒子については，これ までに TEM 観察による研究が数多く報告されている(Palotas, et al., 1996)(Ishiguro, et al., 1997)(Boehman, et al., 2005)(Song, et al., 2006) (Vander Wal and Muller, 2006)(Vander Wal, et al., 2007). しかしディーゼル噴霧火炎内でのす す生成・酸化過程についてより詳細に理解するためには，火炎中のす寸粒子の性状を調べることが望ましい。そ こで本研究は，ディーゼル噴霧火炎内から直接すす粒子を捕集し，TEM 観察及び解析を行い，噴霧火炎中でのす す粒子の生成及び酸化過程を詳細に理解することを目的とする。

ディーゼル噴霧火炎内す寸粒子の挙動を調べるもう一つの方法として，レーザー誘起赤熱法(LII)やレーザー誘 起蛍光法(LIF)などの光学計測による研究がこれまでに数多く報告されている(Kosaka, et al., 1995)(Dec, 1997)(Ito, et al., 2004)(Kosaka, et al., 2005). これらのレーザー計測法はin-situ かつ瞬時性に優れるが，得られるのは計測点に

\footnotetext{
No.15-00348 [DOI:10.1299/transjsme.15-00348], J-STAGE Advance Publication date : 2 October, 2015

*1 正員, 明治大学大学院理工学研究科(干214-8571 神奈川県川崎市多摩区東三田 1-1-1)

*2 正員, 明治大学大学院理工学研究科(現小野測器(株))

*3 明治大学大学院理工学研究科(現(株)堀場製作所)

*4 正員, 明治大学理工学部

E-mail of corresponding author: taizawa@meiji.ac.jp
} 
存在する多数のす寸粒子に対するある種の平均值であり, TEM 解析に比べて定量性に難がある. 同条件下での火 炎内す寸粒子の性状や微細構造が TEM 観察により定量化できれば，レーザー計測結果のより詳細な考察が可能 となる。

Kook 及び Pickett は近年, ジェット燃料を用いた定容容器中の単発噴霧火炎内です寸粒子の直接捕集と TEM 観 察を初めて行い，同時に LII 法及びレーザー透過光減衰法を組み合わせて用いることで噴霧火炎内す寸粒子の定 量濃度計測を行っている(Kook and Pickett, 2011). 筆者らは特に火炎内寸寸粒子の捕集についてこの先行研究の手 法に倣い，これまでに JIS2 号軽油及び大豆由来メチルエステルバイオ燃料を用いたディーゼル噴霧火炎内す寸粒 子性状の TEM 観察・解析を報告している(山口他，2010)(Nerva, et al., 2011)(Aizawa, et al., 2012). しかしながらこ れらの先行研究では，寸寸粒子の火炎内捕集位置はインジェクタ先端から 40, 50, $70 \mathrm{~mm}$ の 3 か所に限られてお り，火炎内す寸粒子の生成及び酸化過程を議論するのに十分な空間分解能とは言えなかった.

そこで本研究では, この空間分解能の不足を補うため, 噴霧火炎中の異なる 6 か所の位置(噴孔から 40〜90 mm) です寸粒子の直接捕集を行った. 著者らは本研究の第一報として, 高速度レーザー影写真法による透過光減衰計 測を行い, 火炎内す寸粒子の挙動観察及び, 光学的す寸濃度と TEM による捕集粒子濃度を比較した結果を報告 している(Yamaguchi, et al., 2012). 本稿ではその続報として, 噴霧火炎中の異なる 6 か所の位置で捕集されたす寸 粒子を TEM 観察し, 得られた画像から要素す寸粒径, 寸寸凝集体の質量分布, 凝集体の構造を解析し, これら の噴孔からの距離に対する変化を調査した結果を報告する.

\section{2. 実験装置及び実験方法}

図 1 に単発ディーゼル噴霧火炎内におけるす寸粒子直接サンプリングに用いた定容燃焼器の概略を示す，燃焼 器は 3 枚の光学空を備えており, 容積は $560 \mathrm{~cm}^{3}$ である. 先端に TEM 観察用グリッドを, 噴霧軸に平行になるよ うに保持した侵襲式サンプラーを図 2 に示すように燃焼器内に設置してす寸粒子の捕集を行った. ノズル先端か ら捕集位置までの距離は燃焼器本体とヘッドの間にスペーサを挟むことで調節した. 主な実験条件を表 1 に示す. アセチレン, 窒素及び酸素の予混合気を火花点火により燃焼させることで, 高温高圧条件 $\left(9.5 \mathrm{~kg} / \mathrm{m}^{3}, 2.5 \mathrm{MPa}, 940\right.$ K)を生成し，単噴孔ノズルを装着したコモンレール式インジェクタを用いて単発燃焼を行った. なお，安全上の

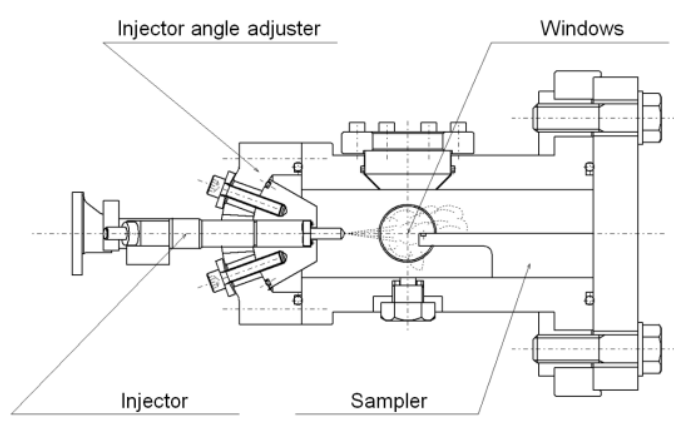

Fig. 1 Constant volume combustion chamber

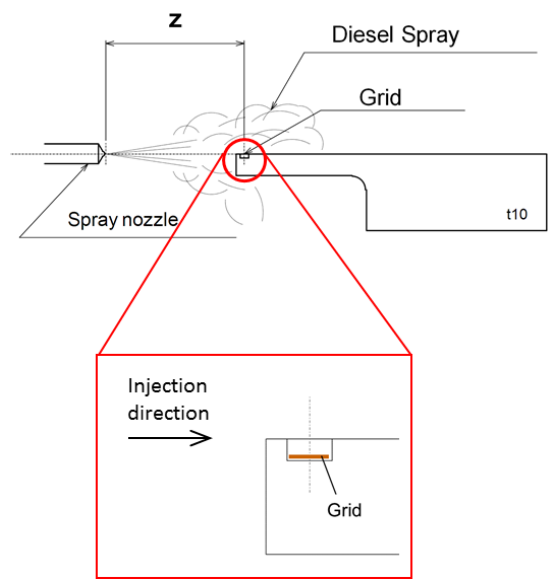

Fig. 2 Side view of soot sampler placed in diesel spray flame
Table 1 Experimental conditions

\begin{tabular}{|l|r|}
\hline \multicolumn{2}{|c|}{ Surrounding Conditions } \\
\hline \hline Ambient gas density: $\rho_{a}$ & $9.5 \mathrm{~kg} / \mathrm{m}^{3}$ \\
\hline Temperature: $T_{a}$ & $940 \mathrm{~K}$ \\
\hline Pressure: $P_{a}$ & $2.5 \mathrm{MPa}$ \\
\hline $\mathrm{O}_{2}$ concentration: $X o_{2}$ & $21 \%$ \\
\hline \multicolumn{2}{|c|}{ Injection conditions } \\
\hline \hline Nozzle & $\phi 0.14 \mathrm{~mm} \times 1$ \\
\hline Injection pressure: $P_{i n j}$ & $80 \mathrm{MPa}$ \\
\hline Injection duration: $\Delta t_{i n j}$ & $2.5 \mathrm{~ms}$ \\
\hline fuel & $\mathrm{JIS} \#$ \\
\hline Injection amount: $M_{f}$ & $10.3 \mathrm{mg}$ \\
\hline \hline \multicolumn{2}{|c|}{ Sampling conditions } \\
\hline \hline Distance from orifice: $z$ & $40,50,60,70,80$ and $90 \mathrm{~mm}$ \\
\hline Grid type & Carbon coated copper grid \\
\hline Temperature of sampler: $T_{\text {sampler }}$ & $373 \mathrm{~K}$ \\
\hline
\end{tabular}

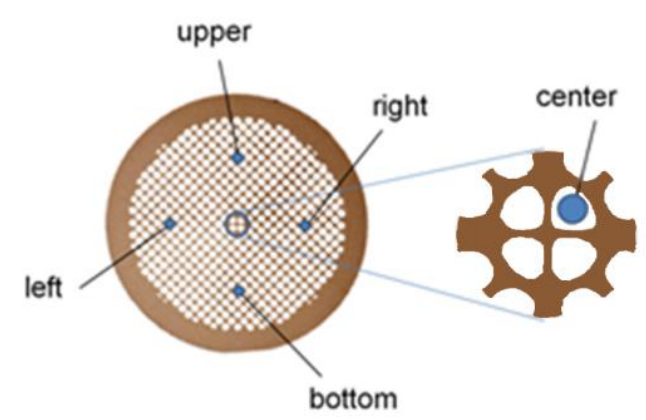

Fig.3 Observation locations on TEM grids 
都合により，本実験での雾囲気条件は近年の自動車用エンジン燃焼室条件と比較して低く設定されているが，次 章で述べられる解析結果は, ディーゼル機関相当雰囲気条件下 $\left(22.8 \mathrm{~kg} / \mathrm{m}^{3}, 6.7 \mathrm{MPa}, 1000 \mathrm{~K}\right)$ で行われた先行研究 (Nerva, et al., 2011)(Aizawa, et al., 2012)のものと粒径絶対值や噴霧軸上での傾向（上流から中流で成長し，下流で酸 化する）においてかけ離れておらず近いものとなっていることから，本稿で得られる結果は，火炎中の寸寸生成 及び酸化を議論するに有用であると考えられる. 本研究では直径 $3 \mathrm{~mm}$, 厚さ $25 \mu \mathrm{m}$ のカーボン支持膜付銅製 TEM 観察用グリッド(STEM, TS-1207，200 メッシュ，支持膜厚さ $30 \mathrm{~nm}$ )を使用した．燃焼器，サンプラー及びグリッ ドは電気ヒーターにより $373 \mathrm{~K}$ に予熱した。 火炎中の寸寸粒子は炏とグリッドの間の温度差により生じる熱泳 動力によってグリッド表面へ捕集される. 本サンプリング手法確立にあたり，著者らの先行研究(相澤他，2011） で, サンプラー侵襲により噴霧火炎の着火遅れ, 熱発生率, 火炎温度, 光学的寸寸濃度に大きく影響を与えてい ないことを調査しており，また，本手法を用いて電子顕微鏡観察に適した量の寸寸粒子が捕集できることを確認 している. また, ディーゼル噴霧火炎の燃焼毎のばらつきにより, どの程度す寸粒子性状が変化するかについて も著者らの先行研究(Kondo, et al., 2013)で調査されている.

ディーゼル噴霧火炎中から直接捕集したす寸粒子は, 透過型電子顕微鏡(JEOM JEM-2100F, 加速電圧 $200 \mathrm{keV}$, 点分解能 $0.19 \mathrm{~nm}$ ) 及び高解像度 CCD カメラ(Gatan Ultrascan 1000/FIRST LIGHT, 撮影解像度 $2048 \times 2048,14 \mu \mathrm{m}$ )を 用いて観察した。噴霧火炎中の寸寸粒子性状を可能な限り維持した状態で観察することを目的に，火炎に暴露し たグリッドは乾燥やアルコールへの溶解分解等の前処理は行わず電子顕微鏡に挿入し観察した. 図 3 に示すよう に，す寸粒子の撮影はグリッド上の異なる 5 つの位置において行った．撮影倍率は統計的に十分な粒子サンプル 数を確保しつつす寸凝集体の形態及び数を把握できる 6,000 倍と, 凝集体内の要素す寸粒子の判別及び粒径計測 が可能な 20,000 倍の 2 種類を用いた.

\section{TEM 画像の解析}

噴霧火炎中から直接捕集したす寸粒子の TEM 画像を 2 值化し，す寸凝集体存在領域のピクセル数を画像上の 全ピクセル数で除算することで，グリッド上に捕集されたす寸粒子の濃度を示す指標としてす寸粒子投影面積比 を算出した．また MATLAB で作成された画像解析プログラムを用いて凝集体内要素す寸粒径 $d_{p}$ を判別が可能な ものに限り手動で計測した. 式(1)より得られる三次元構造を考慮したす寸粒子凝集体内要素す寸粒子数 $n$, 凝集 体毎の平均要素寸寸粒径 $d_{p a}$, 凝集体旋回半径 $R_{g}$, 投影面積 $A$ をそれぞれ式(2)に代入, 解析にかけた全凝集体(た だし $n<3$ の凝集体は除く)に適用し得られるプロットから近似直線を算出し, その傾きを $D_{f}$, 切片を $k_{f}$ とするこ とで, す寸凝集体構造の指標となるフラクタル次元 $D_{f}$ を求めた. 詳細な解析方法については先行研究(Lee, et al., 2000)(Yamaguchi, et al., 2012)を参照されたい. また, 解析に必要な粒子数や解析者間の個人差が解析結果に与える 影響など，本手法の信頼性の検討は著者らの先行研究で議論されている(Kondo, et al., 2013)

$$
\begin{aligned}
& n=\left(\frac{A}{A_{p}}\right)^{\alpha} \\
& \ln n=\ln k_{f}+D_{f} \ln \left(\frac{R_{g}}{d_{p a}}\right) \\
& R_{g}^{2}=\frac{1}{m} \sum r_{i}^{2} \\
& n \quad: \text { 凝集体内要素す寸粒子数 } \\
& A \quad: \text { 凝集体毎の投影面積 }\left[\mathrm{nm}^{2}\right] \\
& A_{p} \quad: \text { 凝集体毎の平均要素す寸粒径から算出された粒子断面積 } A_{p}=\pi d_{p a}^{2} / 4\left[\mathrm{~nm}^{2}\right] \\
& \alpha \quad: \text { 重军補正係数 }(=1.09)(\text { Megaridis and Dobbins, 1990) } \\
& k_{f} \quad: \text { 係数 } \\
& D_{f} \quad: \text { フラクタル次元 } \\
& R_{g} \quad: \text { 凝集体旋回半径 [nm] } \\
& d_{p a} \quad: \text { 凝集体毎の平均要素す寸粒径 }[\mathrm{nm}] \\
& m \quad: \text { す寸凝集体画像を構成するピクセル数 } \\
& r_{i} \quad: \text { 凝集体図心と凝集体を構成する各ピクセル間距離 }[\mathrm{nm}]
\end{aligned}
$$




\section{4. 観察及び解析結果}

\section{4-1 すす粒子 TEM 画像}

ディーゼル噴霧火炎中の噴孔から 40 90 mm の異なる位置で捕集されたす寸粒子の TEM 画像の例を図 4 に示 す. 図 4 の画像の撮影倍率は各捕集位置について上段が 6,000 倍, 下段が 20,000 倍となっている. これらの画像 から, 火炎中から直接捕集したす寸粒子には単独で存在する要素す寸粒子と凝集体が混在していることがわかる.

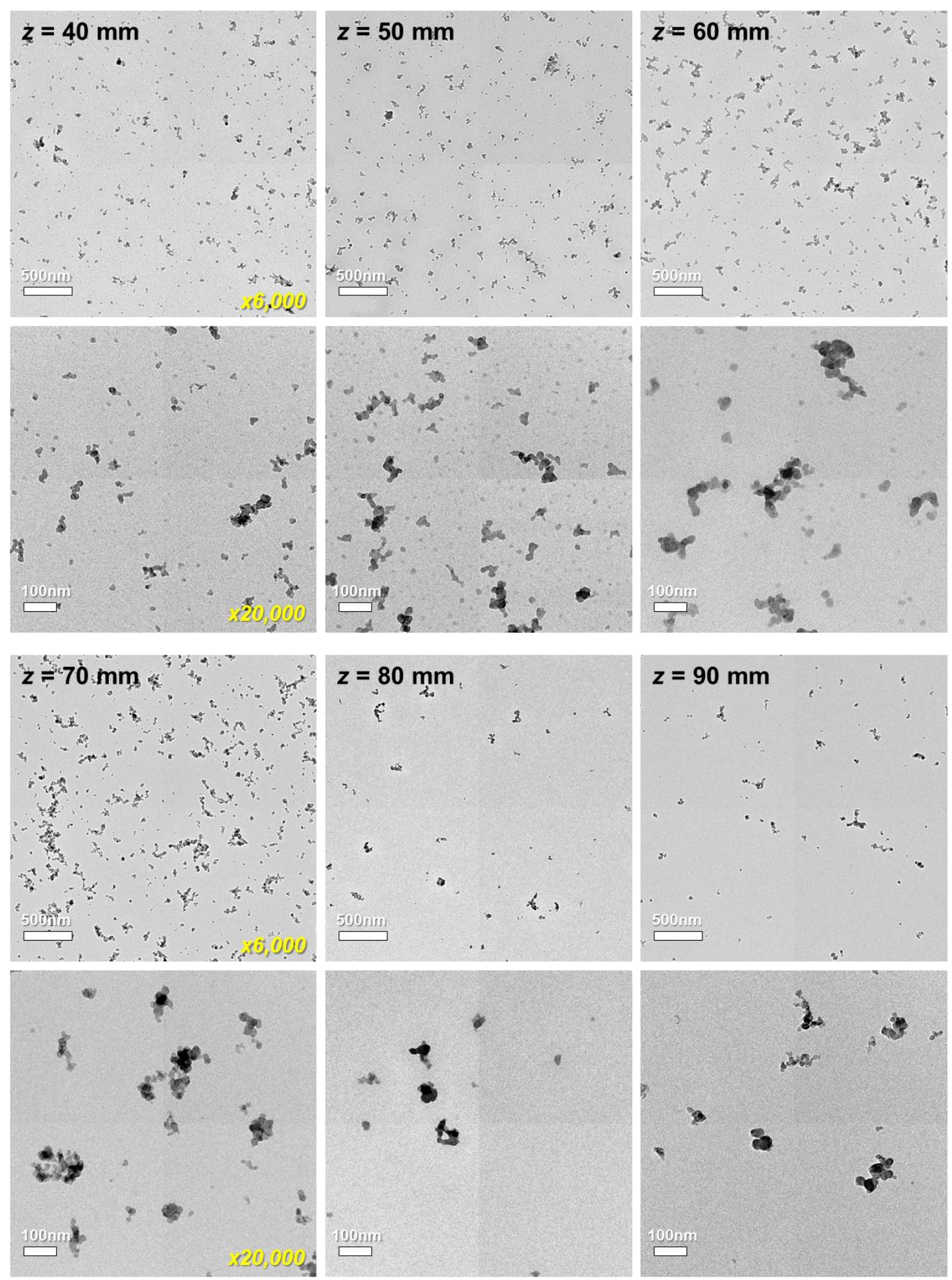

Fig. 4 TEM images of soot particles directly sampled at 6 different axial locations in spray flame at a magnification of $\mathrm{x} 6000$ (top) and $\mathrm{x} 20,000$ (bottom). The sampled soot concentration and aggregate size gradually increases from $40 \mathrm{~mm}$ to $70 \mathrm{~mm}$, then rapidly decreases at $80 \mathrm{~mm}$. 
排気で捕集されるす寸粒子は概ね凝集体であり，その凝集体旋回半径はおよそ 80～130 nm (Lee, et al., 2002)(Zhu, et al., 2005)であることから，今回観察されたす寸粒子はす寸凝集プロセス以前もしくはその間に捕集されたもの であると考えられる. 撮影倍率 6,000 倍の画像から, 捕集位置 $40 \mathrm{~mm}$ から $70 \mathrm{~mm}$ にかけてす寸粒子の濃度及び大 きさが徐々に大きくなっていることがわかる.一方, $70 \mathrm{~mm}$ から $80 \mathrm{~mm}$ にかけてす寸粒子の濃度は急激に隇少し, $70 \mathrm{~mm}$ の位置で見られるような数百 $\mathrm{nm}$ に及ぶ大きな凝集体は $80 \mathrm{~mm}$ では確認されない.また, $80 \mathrm{~mm}$ から $90 \mathrm{~mm}$ にかけては寸寸粒子の濃度, 大きさ共に大きな変化は見られない. これらの寸寸粒子濃度及び大きさの噴孔から の位置に対する変化は，ディーゼル噴霧火炎中での寸寸粒子の生成，成長及び酸化過程を反映しているものと考 えられる. 捕集位置 $40 \mathrm{~mm}, 50 \mathrm{~mm}, 70 \mathrm{~mm}$ において TEM によるす寸粒子性状解析を行った先行研究(山口他, 2010)(Aizawa, et al., 2012)では $50 \mathrm{~mm}$ から $70 \mathrm{~mm}$ にかけての寸寸粒子濃度の減少が著しく, 特に酸化現象の把握 が困難であった，本研究ではこの結果を踏まえ，捕集位置を $10 \mathrm{~mm}$ 刻みとしたが，なお， $70 \mathrm{~mm}$ から $80 \mathrm{~mm} の$ 間のわずか $10 \mathrm{~mm}$ で急激な減少を示しており，噴霧火炎中でのす寸粒子の酸化は生成・成長と比べ，極めて早い 現象であることが推察される. 先行研究において得られた, この撮影倍率 6,000 倍の TEM 画像から算出されたす 寸濃度の指標となる投影面積比を図 5(Yamaguchi, et al., 2012)に示寸. この図からも $40 \mathrm{~mm}$ から $70 \mathrm{~mm}$ にかけて 徐々に増え, $80 \mathrm{~mm}$ で $70 \mathrm{~mm}$ のそれと比べ 5 分の 1 以下に減少していることから, 寸寸粒子の捕集量は酸化によ り急激に減少することが定量的に確認される.

撮影倍率 20,000 倍の画像から, 寸寸粒子の形状及び凝集体を構成する要素す寸粒子の大きさ等の定性的な傾向 を確認することができる. $40 \mathrm{~mm}$ の位置では，多数の単独で存在する小さな要素す寸粒子が観察されたが，下流 に行くにつれ，一粒一粒が大きくなりかつ大きな凝集体を形成していることがわかる，その後，濃度において大 幅な減少が見られた $80 \mathrm{~mm}$ の位置では凝集体は小さくなっているものの, 内部の要素す寸粒子に大きな変化は見 られない．また，火炎中のどの位置においても鎖状の凝集体が多く見られ，その数及び大きさに違いはあるもの の，火炎全体を通して，その形状に大きな変化は見られない.

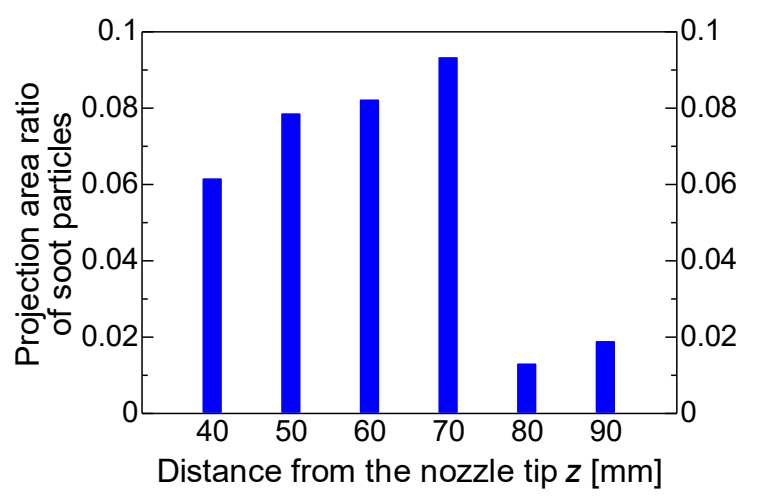

Fig. 5 Projected area ratio of soot particles directly sampled in diesel spray flame at 40 to $90 \mathrm{~mm}$ from the injector nozzle. The concentration of soot gradually increases from $40 \mathrm{~mm}$ to $70 \mathrm{~mm}$, then sharply decreases at $80 \mathrm{~mm}$. While there are few differences between $80 \mathrm{~mm}$ and $90 \mathrm{~mm}$. This analysis was conducted in the previous study (Yamaguchi, et al., 2012).

\section{$4 \cdot 2$ 要素すす粒径}

ここでは，噴霧火炎内す寸粒子の要素す寸粒径解析結果について述べる．この解析には，凝集体内の要素す寸 粒子の形状を認識するのに適した撮影倍率 20,000 倍の TEM 画像を用いた. TEM 画像上において, 単独で存在す る要素す寸粒子の判別は比較的容易だが, 複雑な 3 次元構造を有する凝集体内の要素す寸粒子の外周を 2 次元投 影像から判別するのは極めて複雑な作業であり, 汎用画像解析ソフト等による判別は現段階では困難である. 本 研究ではある一定の経験(Kondo, et al., 2013)を積んだ解析者が手作業で TEM 画像中の要素す寸粒子を判別し, 上 述の MATLAB で作成された画像解析プログラムでデータの整理, 保存, 解析を行った. 計測は形状を認識でき る要素す寸粒子についてのみ行った。また，形が円形でない物も多く存在するため，それぞれの要素す寸粒子に 対し 2 軸方向に計測を行った. 要素す寸粒径の解析には単独で存在するもの, 凝集体内のものの両方が含まれて いる. 
図 6 に噴霧火炎中の異なる 6 か所の位置で捕集されたすす粒子の要素す寸粒径ヒストグラムを示す．各ヒスト グラムはそのピークの值で正規化されている. 要素す寸粒径の総計測数は, 噴孔から $40 \mathrm{~mm}$ の位置から順に, 4778, 5245，3594，5354，2966，3564 回である. なお，通常撮影倍率 20,000 倍の画像 25 枚を解析するが， $80 \mathrm{~mm}$ 及び $90 \mathrm{~mm}$ の位置についてはす寸粒子の捕集量が少なかったため, 統計的に十分な量のサンプル数(Kondo, et al., 2013) を満たす目的で 50 枚ずつ解析を行った. 図中の黒点は算術平均值を示している. 要素すす粒径は捕集位置 $40 \mathrm{~mm}$ から $60 \mathrm{~mm}$ にかけて増加し，その後下流に進むに従って減少していることがわかる．上流から中流にかけて増加 し，下流で減少するという傾向は，火炎中の生成及び酸化過程を反映していると考えられ，図 5 に見られるす寸 粒子投影面積比のものとも概ね一致している．しかしながら，そのピークの位置や下流での減少の程度等，要素 す寸粒径と投影面積比の間には相違点も見られる.

また，噴霧火炎内から直接捕集された今回の要素す寸粒径は 12～20 nm 程度であるのに対し，排気管中で捕集 されたものは20〜35 nm 程度(Lee, et al., 2002)(Zhu, et al., 2005) と, 火炎中の最大粒径よりも大きい值を示している. 温度や密度の低下した排ガス中です寸粒子の表面成長が起こっているとは考えにくく，実験装置や条件の違いに 留意する必要はあるが，実エンジン筒内では然焼中から排気行程に至るまでの間に要素す寸粒径に影響を与える 何らかの現象が起きていることが推察される.

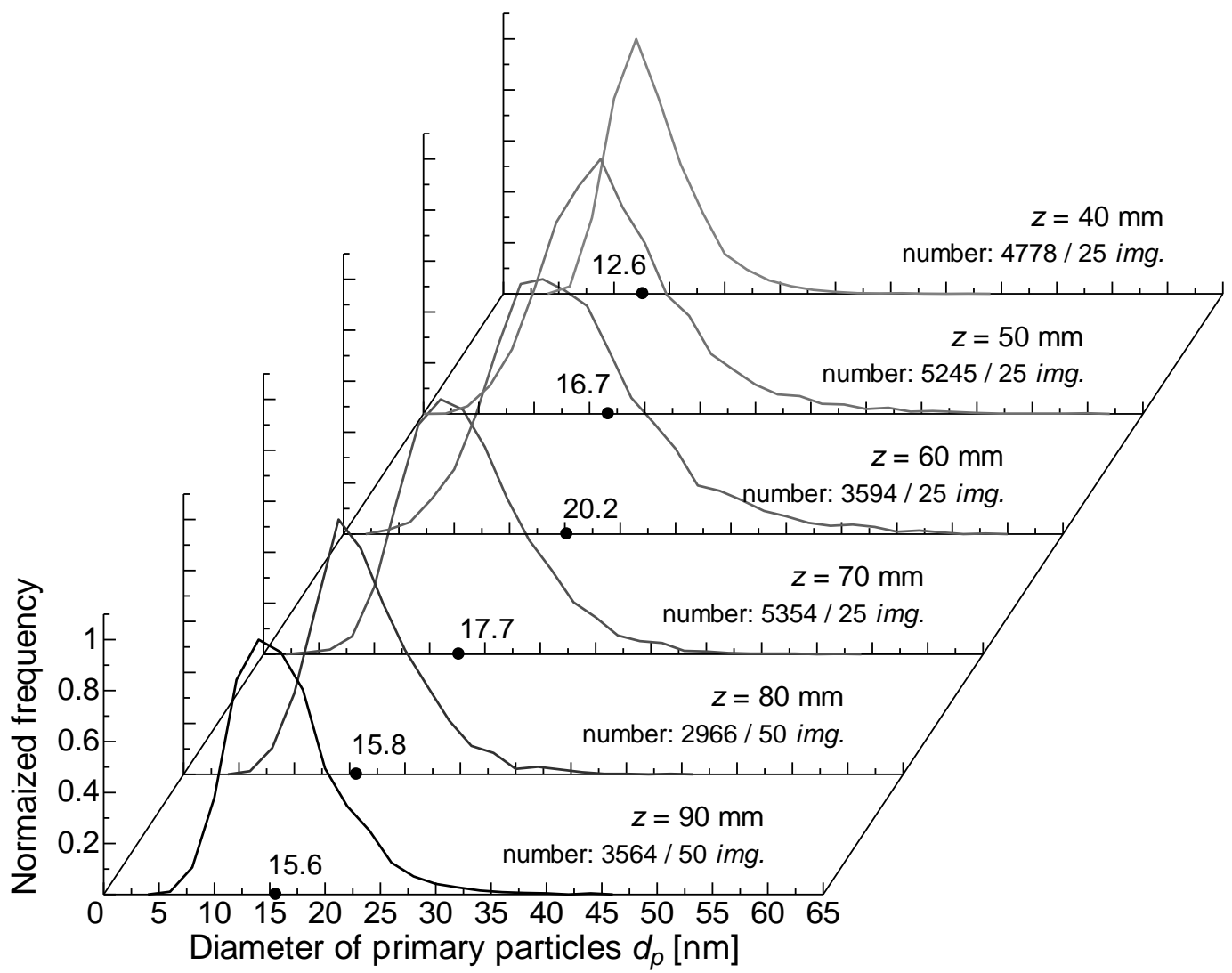

Fig. 6 Normalized histogram of diameter of primary particles directly sampled at 6 different axial locations in diesel spray flame. The average diameter of primary particles started at $12.6 \mathrm{~nm}$ at $z=40 \mathrm{~mm}$, increased to $20.2 \mathrm{~nm}$ at $z=60 \mathrm{~mm}$, and then decreased to $15.6 \mathrm{~nm}$ at $z=90 \mathrm{~mm}$. This trend is similar to that of the projected area ratio shown in Fig. 5, and seems to reflect the soot formation and oxidation processes in a diesel spray flame.

\section{4-3 すす凝集体旋回半径}

ここでは，噴霧火炎内す寸粒子の凝集体旋回半径解析結果について述べる．解析には撮影倍率 6,000 倍の TEM 画像を用いた．撮影倍率 6,000 倍の TEM 画像は，す寸凝集体の形状を認識することが容易であるのに加え，統計 的に十分な数の凝集体サンプルを撮影するのに適している(Kondo, et al., 2013). 本研究では単独で存在する要素す す粒子も凝集体として含まれている，火炎中のす寸粒子は単独で存在する要素す寸粒子や比較的小さな凝集体が 多く, 算術平均値は小さくなる傾向にある(山口他, 2010)(Kook, et al., 2013). しかしながら, 数にして少量の大き 
な凝集体でも質量としては大きな割合を占めるため，す寸排出量を考慮した場合には潜在的に重要になる．そこ で本研究では，凝集体旋回半径ヒストグラムに質量重み付けをし，質量分布を得ることで凝集体の火炎中での大 きさの変化を評価することとした，その詳細な算出方法については先行研究(Yamaguchi, et al., 2012)を参照された い.

図 7 に噴霧火炎中の異なる 6 か所で捕集したす寸粒子の凝集体旋回半径の質量分布を示寸．解析にかけられた 凝集体数は，噴孔から $40 \mathrm{~mm}$ の位置から順に，1951，1544，1098，1203，302，344 個である．捕集位置 $40 \mathrm{~mm}$ 及び $50 \mathrm{~mm}$ では他の位置に比べ計測された凝集体数が多い.これは火炎上流域で捕集されたす寸粒子には，核生 成後間もないと考えられる単独で存在する要素す寸粒子が多数含まれるためである. その後計測数が減少すると 共に質量重み付け平均旋回半径は増加し, 図 5 に示された投影面積比と同様, $70 \mathrm{~mm}$ の位置でピークを示す.こ のことから，凝集体は濃度の増加による衝突凝集を伴いながら成長していることがわかる．その後凝集体旋回半 径は $80 \mathrm{~mm}$ の位置で, 投影面積比程ではないものの, 明らかな減少を示している. このことから, 凝集体の大き さも上流から中流にかけて増加し，下流で減少するという投影面積比及び要素寸寸粒径で見られたものと共通の 傾向を示し，またこれらは火炎中の生成・酸化過程を反映していると考えられる.

本研究で噴霧火炎内から直接捕集された凝集体質量重み付け平均旋回半径は 26〜 58 nm 程度であるのに対し, 排気管中で捕集されたものは算術平均值であるにも関わらず 80〜130 nm 程度(Lee, et al., 2002)(Zhu, et al., 2005) と 大きい值を示している，凝集体については排気管内で粒子同士の衝突により凝集が進むことも考えられるが，こ こで見られる差は大きく，このことも要素す寸粒径で見られた傾向と同様，燃焼中から排気行程までの間に筒内 で凝集体サイズに影響を与える何らかの現象が起きていることを示唆している.

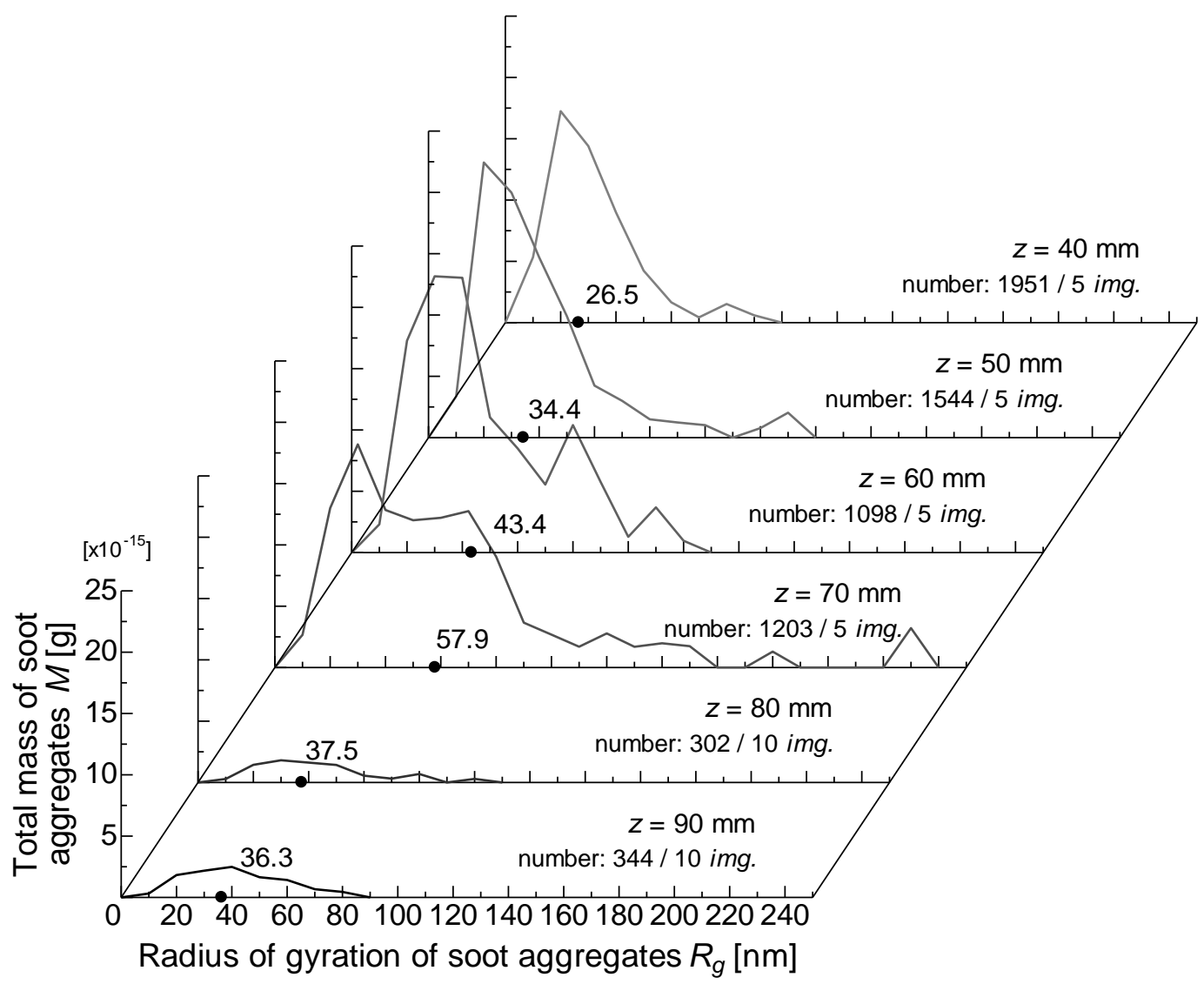

Fig. 7 Mass distribution of soot aggregate size directly sampled at 6 different axial locations in diesel spray flame. The average of the mass-weighted radius of gyration started at $26.5 \mathrm{~nm}$ at $z=40 \mathrm{~mm}$, increased to $57.9 \mathrm{~nm}$ at $z=70 \mathrm{~mm}$, and then decreased to $36.3 \mathrm{~nm}$ at $z=90 \mathrm{~mm}$. Again, this trend is similar to those seen in the results of projected area ratio and primary particle diameter, and seems to reflect the soot formation and oxidation processes in a diesel spray flame. 


\section{$4 \cdot 4$ フラクタル次元}

ここでは，噴霧火炎内す寸粒子の凝集特性を定量評価するため，上述の式(1)（3)を用いて算出したす寸凝集体 のフラクタル次元の結果について述べる. フラクタル次元の算出には凝集体毎の平均要素す寸粒径が必要である ため, 解析には要素す寸粒子の形状把握に適した撮影倍率 20,000 倍の TEM 画像を使用した。火炎内寸寸粒子に は単独で存在する要素す寸粒子等も多く含まれているが, 要素す寸粒子 3 個未満で構成されている凝集体は凝集 特性の評価には適さないので，本研究では単量体及び二量体はフラクタル次元算出には用いていない.

図 8 に噴霧火炎中の異なる 6 か所で捕集したす寸粒子のフラクタル次元算出結果を示す. 図 8 の黒い実線は捕 集位置 6 か所のフラクタル次元の平均值(=1.73)を示しており, フラクタル次元は捕集位置によらずほぼ一定の值 をとっていることがわかる．このことから，寸寸凝集体の構造はディーゼル噴霧火炎中の位置によって変わらな いことがわかる. また，このフラクタル次元 1.73 という值は，凝集体同士が衝突した場合，高い確率で付着・凝 集するという拡散律速凝集により火炎内す寸粒子が成長していることを示唆している(Schaefer, 1988)(Megaridis and Dobbins, 1990). また，大豆由来メチルエステルバイオディーゼル噴霧火炎中(Nerva, et al., 2011)及び US2 号軽 油を使用したディーゼルエンジンの排気中(Lee, et al., 2002)の凝集体のフラクタル次元も図 8 中に示している. バ イオディーゼル噴霧火炎中の凝集体のフラクタル次元も捕集位置によらずほぼ一定であり, 本研究結果と似た傾 向を示したが，その平均值は図中の破線で示寸ように 1.68 と，JIS2 号軽油のものよりもやや低かった. 一般に， 凝集体同士が衝突した際の付着確率が高いほどフラクタル次元が低くなる傾向にあり，また，付着確率が高くな ることで凝集速度も上昇し，短時間でより大きな凝集体を形成することがわかっている(松下，2002). 図 8 に示 しているバイオディーゼル噴霧火炎中の凝集体も，同条件下で捕集された従来軽油のもの及び本研究のものより も大きくなる傾向にあり(Aizawa, et al., 2012), これに矛盾しない. 要素寸寸粒子内部の微細構造においてもバイ オディーゼル燃料は従来軽油に比べ，よりアモルファス的な構造となる傾向にあり(Song, et al., 2004), これらの 結果から，燃料成分がす寸粒子の核生成及び凝集過程に影響を及ぼしていると考えられる，一方で，JIS2 号軽油 と US2 号軽油の燃料性状の違いには留意しなければならないが，排気中のす寸凝集体のフラクタル次元は 1.84 であり，火炎中のものよりも高い值を示している．火炎中で変化のなかった凝集体構造が排気中の寸寸粒子にお いて変化していることから，燃焼中から排気行程，また排気管内で凝集の律速過程に何らかの影響を与える現象 が起きていることが考えられる.

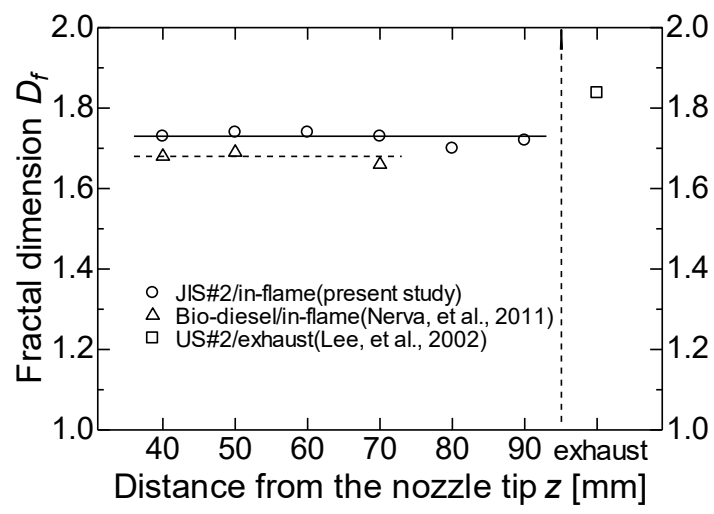

Fig. 8 Plots of fractal dimension of soot particles directly sampled in JIS\#2 and bio diesel spray flame(Nerva, et al., 2011) and from exhaust gas stream(Lee, et al., 2002). The fractal dimension is almost constant around the average of 1.73 over different axial locations. The fractal dimension for the bio in-flame soot shows a similar general trend, being almost constant over different axial locations in the spray flame, but slightly lower average value of 1.68 than conventional diesel soot. On the other hand, the fractal dimension of the exhaust soot, 1.84, is higher than the one for the in-flame soot. Therefore the fuel chemical components as well as the in-cylinder combustion processes including spray wall impingement may potentially affect the aggregation processes.

噴孔からの距離に対する上述の各種計測結果の傾向を概観するため, 要素す寸粒径と凝集体旋回半径の平均值 及び先行研究で得られたす寸粒子投影面積比と光学的す寸濃度(Yamaguchi, et al., 2012)を, それぞれの最大值で正 規化したものを図 9 に示す. ディーゼル噴霧火炎中の異なる位置における要素す寸粒径及びす寸凝集体旋回半径 は投影面積比の傾向と同様，火炎上流から中流域にかけて増加し， $z=60,70 \mathrm{~mm}$ でピークを示し，下流域で減少 
するという傾向があることがわかった．これらの増加及び減少の傾向はそれぞれ火炎中での寸寸粒子の生成及び 酸化に対応していると考えられる.

しかしながら, 各パラメータ解析結果の異なる位置における挙動を細かく見ると, 要素す寸粒径のピーク位置 が噴孔先端から $60 \mathrm{~mm}$ であるのに対し，凝集体旋回半径のそれは $70 \mathrm{~mm}$ と，相違点があることに気づく. 図 6 から, 要素す寸粒径は $60 \mathrm{~mm}$ から $70 \mathrm{~mm}$ にかけてヒストグラムが左側へシフトし, 全体的に小さくなっている ことがわかる. $70 \mathrm{~mm}$ の位置よりさらに下流の $80 \mathrm{~mm}$ においてもヒストグラムは左側へシフトし減少傾向にある ことから，70 mm で要素す寸粒子の酸化による縮小が始まっていると考えられる. 一方，図 7 から凝集体旋回半 径は $60 \mathrm{~mm}$ から $70 \mathrm{~mm}$ にかけて, $30 \mathrm{~nm}$ を下回る比較的小さな凝集体の分布に大きな変化は見られないものの, $50 \mathrm{~nm}$ を超える大きな凝集体が明らかに増えており, 凝集成長が $70 \mathrm{~mm}$ においても継続していることが推察され る.これらより, $60 \mathrm{~mm}$ から $70 \mathrm{~mm}$ にかけて要素す寸粒子と凝集体旋回半径の大きさの傾向は明らかに異なって おり，またこのことは，70 mm において凝集体を構成する要素す寸粒子は小さくなっているにも関わらず，凝集 体そのものの成長は進行していることを意味している．このことからディーゼル噴霧火炎中の凝集体成長過程は それを構成する要素す寸粒子一粒一粒の表面成長ではなく, 凝集体同士の衝突凝集によって支配されていると考 えられる.

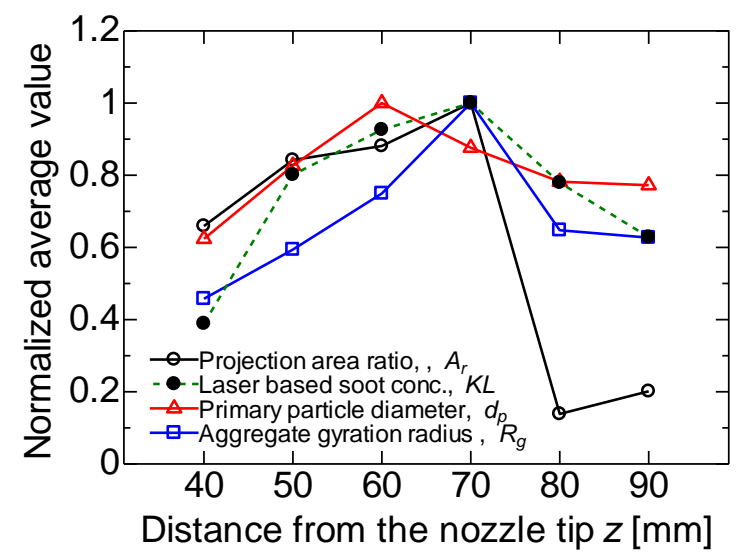

Fig. 9 Plots of projection area ratio, local relative soot concentration and average values of primary particle diameter and aggregate gyration radius in different axial locations. All parameter show similar general trend, increasing at the upstream $(z=40,50 \mathrm{~mm})$, exhibiting peak at mid-stream $(60,70 \mathrm{~mm})$ then decreasing at the downstream $(80,90 \mathrm{~mm})$. However, there are also some discrepancies such as the different size peak between primary particle and aggregate and huge drop of projection area ratio at $z=80 \mathrm{~mm}$.

また図 9 より, 噴孔先端から $80 \mathrm{~mm}$ の位置において投影面積比が急激に減少している傾向が確認される. 上述 したようにこの減少は火炎中での寸寸の酸化を反映していると考えられる，一方，凝集体旋回半径及び要素す寸 粒径も $80 \mathrm{~mm}$ で減少する傾向にはあるものの，投影面積比程ではない．この理由として火炎中の寸寸粒子が不均 一に酸化され，酸化を逃れた，もしくは酸化されきらずに残った粒子がグリッドに捕集されていることが考えら れる. しかしながら，図 9 の破線で示されている，本サンプリングと同時に撮影された高速度レーザ一影写真か ら算出したグリッド近傍の局所相対す寸濃度(Yamaguchi, et al., 2012)は, TEMによる解析で得られた投影面積比と は大きな差を示している. また, 栗林らが本研究と同様の条件下でLII/LS 法により計測した光学的す寸濃度・粒 径・数密度分布(Kuribayashi, et al., 2013)( Kuribayashi, et al., 2014)を図 10 に示す. 使用された燃料が FTD 燃料であ ること，また，パルスレーザーによる瞬時計測で得られた分布であることに留意する必要があるが，この図から 本研究で酸化が支配的となっているとされる 80 90 mm の領域以降においても粒径は増加していることがわか り, TEM 解析で得られた凝集体旋回半径及び要素寸寸粒径の傾向とも一致しない. これらの光学計測結果との相 違点から，噴霧火炎中の寸寸粒子の捕集メカニズムの支配因子を明らかにする必要がある，具体的には，グリッ ド設置部近傍の火炎中心温度は下流に行くに従い温度が上昇する傾向にあり(Harada, et al., 2013), この火炎温度の 変化がす寸粒子捕集時に生じているとされる熱泳動効果一与える影響が挙げられる.また同様に，上流から下流 にかけて噴霧火炎の流速は大きく変化しており，この流速の変化が温度勾配，さらには熱泳動効果に影響を与え 


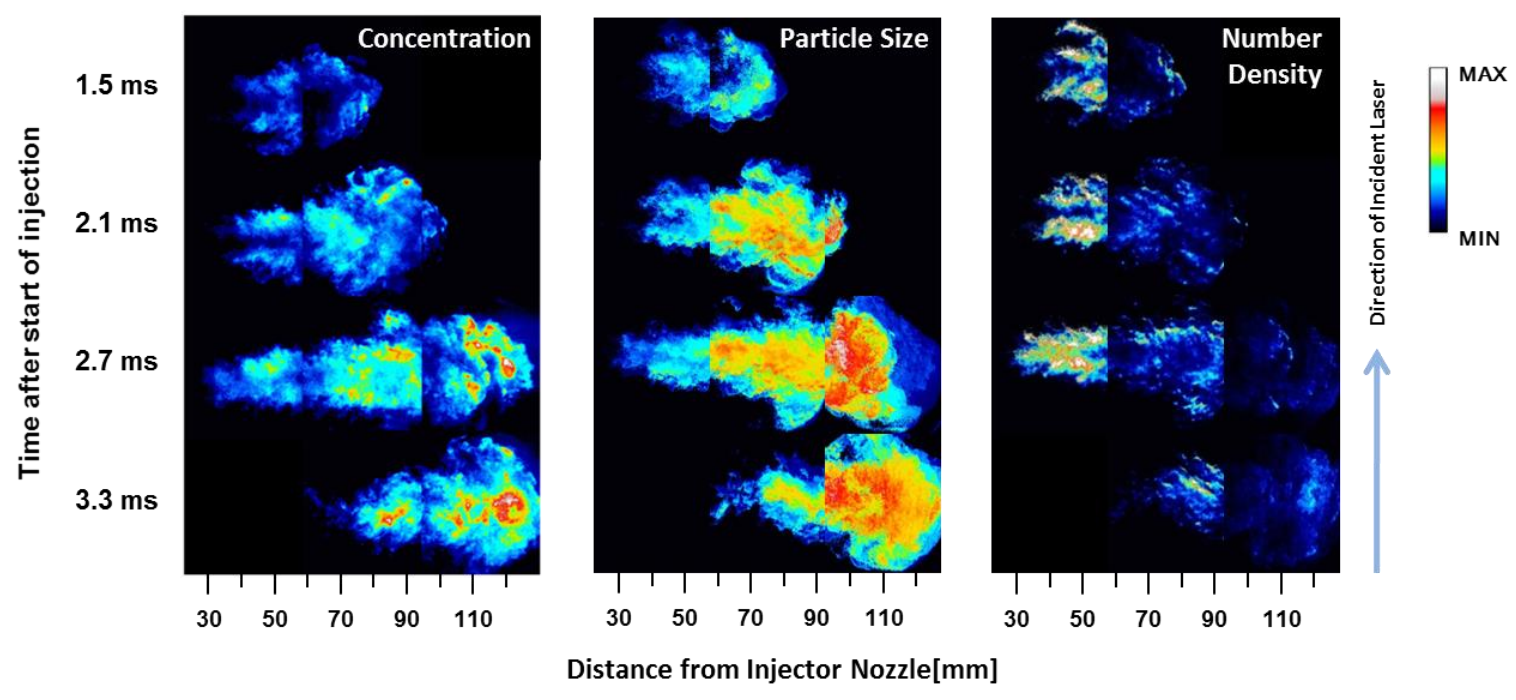

Fig. 10 Spontaneous 2-D distribution of relative soot concentration (left), particle size (middle) and number density (right) at different timings in FTD fuel reacting jet via LII/LS technique (Kuribayashi, et al., 2013). The in-flame concentration, particle size and number density are heavily inhomogeneous distribution both temporally and spatially. The particle size continues to grow up toward the downstream even after $z=90 \mathrm{~mm}$ where TEM based particle size becomes smaller due to the oxidation.

ていることが考えられる.これら熱泳動効果への影響を調査するため，今後，サンプリング中のグリッド温度を 計測し，各捕集位置における熱泳動力を比較する必要がある．また，現在のサンプリング方法ではす寸粒子捕集 用グリッドが然焼の終始に渡り火炎に暴露されているが, 図 10 からもわかるように火炎中のす寸粒子濃度及び粒 径は位置だけでなくタイミングによっても変化しており，どのタイミングの粒子群がどの程度グリッド上に捕集 されているかが明らかになっていない。この捕集タイミング毎のす寸粒子性状を調査するために今後，シャッタ 一機構を用いた時間分解サンプリング(服部，相澤，2014)により火炎内粒子を異なるタイミングで捕集し，その 性状を比較する必要がある。

\section{5. 結 言}

ディーゼル噴霧火炎中の異なる位置で直接捕集したす寸粒子を透過型電子顕微鏡(TEM)で観察し，要素す寸粒 径，す寸凝集体旋回半径，フラクタル次元などを解析した．得られた結果は以下の通りである.

（1） ディーゼル噴霧火炎中から直接捕集したすす粒子には単独で存在する要素すす粒子と凝集体が混在した. 要素す寸粒径及び凝集体旋回半径は，上流(噴孔から $50 \mathrm{~mm}$ まで)で増加，中流(70 mm まで)でピークを示 し，下流(80 mm 以降)で減少するというす寸粒子投影面積比で見られたものと近い傾向を示した. この傾 向は火炎中のす寸生成・酸化過程を反映しているものと考えられる.

(2) 要素す寸粒径は噴孔 $60 \mathrm{~mm}$ の位置でピークを示したのに対し，凝集体旋回半径は $70 \mathrm{~mm}$ と，2つのパラ メータ間で相違点が見られた。このことからディーゼル噴霧火炎中の凝集体成長過程はそれを構成する要 素す寸粒子一粒一粒の表面成長ではなく，凝集体同士の衝突凝集によって支配されていると考えられる.

(3) すす凝集体のフラクタル次元は噴霧火炎内の位置によって変わらず 1.73 程度となった. また，この 1.73 という值から噴霧火炎内す寸粒子の凝集メカニズムは拡散律速となっていると考えられる.

(4) それぞれの火炎中のピーク位置における平均要素す寸粒径及び質量重み付け平均凝集体旋回半径最大值 はそれぞれ $20 \mathrm{~nm}$ 及び $58 \mathrm{~nm}$ であり，排気中で捕集されるものより小さかった．さらに火炎内す寸粒子の フラクタル次元も従来より観察されている排気中のものよりも低い值を示した. このことから実エンジン 筒内では，然焼中から排気行程に至るまでにす寸粒子性状に影響を与える現象が起きていることが考えら れる. 
謝辞

本研究の実施にあたり, TEM によるす寸粒子観察の機会を提供して頂いた明治大学理工学部物理学科吉村英恭 氏，また本研究を進めるにあたり有益な議論をして頂いた米国サンディア国立研究所の Lyle Pickett 氏に感謝申し 上げる.

\section{文献}

相澤哲哉, 猪熊洋希, 山口輝夫, 藤原章, 井上哲, 高分解能透過型電子顕微鏡を用いたディーゼル噴霧火炎内寸寸 粒子の観察, 日本設計工学会誌 Vol.46, No.8 (2011), pp.461-467.

Aizawa, T., Nishigai, H., Kondo, K., Yamaguchi, T., Nerva, J. G., Genzale, C., Kook, S. and Pickett, L. M., Transmission electron microscopy of soot particles directly sampled in diesel spray flame - A comparison between US\#2 and biodiesel soot, SAE International Journal of Fuels and Lubricants, Vol.5, No.2 (2012), pp.665-673, DOI:10.4271/2012-01-0695.

Boehman, A. L., Song, J. and Alam, M., Impact of biodiesel blending on diesel soot and the regeneration of particulate filters, Energy and Fuels, Vol.19 (2005), pp.1857-1864, DOI:10.1021/ef0500585.

Bockhorn, H. (ed.), Soot formation in combustion - Mechanisms and Models (1994), p.177 and p.427, Springer-Verlag.

Dec, J., A conceptual model of DI diesel combustion based on laser-sheet imaging, SAE Technical Paper 970873 (1997), DOI: $10.4271 / 970873$.

服部佑紀，相澤哲哉，高速度シャッターを用いたディーゼル噴霧火炎内寸寸粒子の時間分解サンプリング, 日本機 械学会・自動車技術会共催第 25 回内燃機関シンポジウム講演論文集 No.19 (2014).

Harada, T., Koga, N., Aizawa, T., Adachi, T. and Kusaka, J., Diesel spray flame using $50 \mu \mathrm{m}$ thin-wire type-R thermocouple, Proceedings of the 24th Internal Combustion Engine Symposium No.51 (2013).

Heywood, J. B. (ed.), Internal combustion engine fundamentals, (1988), p.631, pp.645-646, McGraw-Hill.

Ishiguro, T., Takatori, Y. and Akihama, K., Microstructure of diesel soot particles probed by electron microscopy: First observation of inner core and outer shell, Combustion and Flame, Vol.108 (1997), pp.231-234, DOI: 10.1016/S0010-2180(96)00206-4.

Ito, T., Hosaka, T., Ueda, M., Senda, J. and Fujimoto, H., Detailed kinetic modeling and laser diagnostics of soot formation process in diesel jet flame, SAE Technical Paper 2004-01-1398 (2004), DOI:10.4271/2004-01-1398.

Kondo, K., Aizawa, T., Kook, S. and Pickett, L., Uncertainty in sampling and TEM analysis of soot particles in diesel spray flame, SAE Technical Paper 2013-01-0908 (2013), doi:10.4271/2013-01-0908.

Kook, S. and Pickett, L. M., Soot volume fraction and morphology of conventional and surrogate jet fuel sprays at 1000-K and 6.7-MPa ambient conditions, Proceedings of Combustion Institute, Vol.33, No.2 (2011), pp.2911-2918, DOI:10.1016/j.proci.2010.05.073.

Kook, S., Zhang, R., Szeto, K., Pickett, L. and Aizawa, T., In-flame soot sampling and particle analysis in a diesel engine, SAE International Journal of Fuels Lubricants, Vol.6, No.1 (2013), pp.80-97, DOI:10.4271/2013-01-0912.

Kosaka, H., Nishigaki, T., Kamimoto, T. and Harada, S., A study on soot formation and oxidation in an unsteady spray flame via laser induced incandescence and scattering techniques, SAE Technical Paper 952451 (1995), DOI:10.4271/952451.

Kosaka, H., Aizawa, T. and Kamimoto, T., Two-dimensional imaging of ignition and soot formation processes in a diesel flame, International Journal of Engine Research, Vol.6, No.1 (2005), pp.21-42, DOI:10.1243/146808705X7347.

Kuribayashi, M., Ishizuka, Y. and Aizawa, T., Sizing of soot particles in diesel spray flame -A qualitative comparison between TEM analysis and LII/scattering laser measurements, SAE International Journal of Fuels and Lubricants, Vol.6, No..3 (2013), pp.641-650, DOI:10.4271/2013-01-2576.

Kuribayashi, M., Mizutani, Y., Ishizuka, Y., Taki, N. and Aizawa T., Effects of ambient oxygen concentration on soot processes in diesel spray flame - A qualitative comparison between TEM analysis and LII/Scattering laser measurements, SAE International Journal of Fuels and Lubricants, Vol.7, No.3 (2014), pp.693-703, DOI:10.4271/2014-01-2642. 
Lee, K. O., Megaridis, C. M., Zelepouga, S., Saveliev, A. V. and Kennedy, L. A., Soot formation effects of oxygen concentration in the oxidizer stream of laminar coannular nonpremixed methane/air flames, Combustion and Flame, Vol.121 (2000), pp.323-333, DOI:10.1016/S0010-2180(99)00131-5.

Lee, K. O., Cole, R., Sekar, R., Choi, M. Y., Kang, J. S., Bae, C. S. and Shin, H. D., Morphological investigation of the microstructure, dimensions, and fractal geometry of diesel particulates, Proceedings of Combustion Institute, Vol.29 (2002), pp.647-653, DOI:10.1016/S1540-7489(02)80083-9.

Li, Z., Song, C., Song, J., Lv, G., Dong, S. and Zhao, Z., Evolution of the nanostructure, fractal dimension and size of in-cylinder soot during diesel combustion process, Combustion and Flame, Vol.158, No.8 (2011), pp.1624-1630, DOI:10.1016/j.combustflame.2010.12.006.

松下貢, フラクタルの物理(I) 基礎編, 裳華房フィジックスライブラリー(2002), pp.130-140.

Megaridis, C. M. and Dobbins, R. A., Morphological description of flame-generated materials, Combustion Science and Technology, Vol.71 (1990), pp.95-109, DOI:10.1080/00102209008951626.

Nerva, J., Yamaguchi, T., Iguma, H., Nishigai, H., Kondo, K., Takano, S., Aizawa, T., Genzale, C. L. and Pickett, L. M., Transmission electron microscopy of soot particles sampled directly from a biodiesel spray flame, SAE Technical Paper 2011-01-2046 (2011), DOI:10.4271/2011-01-2046.

Palotas, A. B., Rainey, L. C., Feldermann, C. J., Sarofim, A. F. and Vander Sande, J. B., Soot morphology: An application of image analysis in high-resolution transmission electron microscopy, Microscopy Research and Technique, Vol.33 (1996), pp.266-278, DOI:10.1002/(SICI)1097-0029(19960215)33:3<266::AID-JEMT4>3.0.CO;2-O.

Schaefer, D.W., Fractal models and the structure of materials, MRS Bulletin, Vol.13, No.2 (1988), pp.22-27, DOI: dx.doi.org/10.1557/S088376940006632X.

Song, J., Alam, M. and Boehman, A.L., Characterization of diesel and biodiesel soot, Preprints of Papers -American Chemical Socienty, Devision of Fuel Chemistry, Vol. 49, No.2 (2004), pp.767-769.

Song, J., Alam, M., Boehman, A. L. and Kim, U., Examination of the oxidation behavior of biodiesel soot, Combustion and Flame, Vol.146 (2006), pp.589-604, DOI:10.1016/j.combustflame.2006.06.010.

Vander Wal, R. L., Yezerets, A., Currier, N. W., Kim, D. H. and Wang, C. M., HRTEM Study of diesel soot collected from diesel particulate filters, Carbon,Vol.45 (2007), pp.70-77, DOI:10.1016/j.carbon.2006.08.005.

Vander Wal, R. L. and Mueller, C. J., Initial investigation of effects of fuel oxygenation on nanostructure of soot from a direct-injection diesel engine, Energy and Fuels, Vol.20 (2006), pp.2364-2369, DOI:10.1021/ef060201+Publication Date (Web): September 14, 2006.

山口輝夫, 猪熊洋希, 西貝大樹, 近藤克文, 高野智識, 相澤哲哉, Nerva, J., Genzale, C.L., Pickett, L.M., 高分解能透 過型電子顕微鏡を用いたディーゼル噴霧火炎内す寸粒子の観察 (2)（バイオディーゼル噴霧火炎内すす粒子 の性状), 日本機械学会・自動車技術会共催第 21 回内燃機関シンポジウム講演論文集 (2010), 講演番号 B7-3.

Yamaguchi, T., Kondo, K., Nishigai, H., Takano, S. and Aizawa, T., Direct sampling, TEM analysis and optical measurement of soot particles at different axial locations in a transient spray flame, SAE International Journal of Fuels Lubricants, Vol.5, No.1 (2012), pp.316-328, DOI:10.4271/2011-01-2051.

Zhang, R. and Kook, S., Structural evolution of soot particles during diesel combustion in a single-cylinder light-duty engine, Environmental Science and Technology (2014).

Zhu, J., Lee, K. O., Yozgatligil, A. and Choi, M. Y., Effects of engine operating conditions on morphology, microstructure, and fractal geometry of light-duty diesel engine particulates, Proceedings Combustion Institute, Vol.30 (2005), pp.2781-2789, DOI:10.1016/j.proci.2004.08.232.

\section{References}

Aizawa, T., Iguma, H., Yamaguchi, T., Fujiwara, S. and Inoue, A., High-resolution transmission electron microscopy of soot particles in diesel spray flame, Journal of Design Engineering, Vol.46, No.8 (2011), pp.461-467 (in Japanese). 
Aizawa, T., Nishigai, H., Kondo, K., Yamaguchi, T., Nerva, J. G., Genzale, C., Kook, S. and Pickett, L. M., Transmission electron microscopy of soot particles directly sampled in diesel spray flame - A comparison between US\#2 and biodiesel soot, SAE International Journal of Fuels and Lubricants, Vol.5, No.2 (2012), pp.665-673, DOI:10.4271/2012-01-0695.

Boehman, A. L., Song, J. and Alam, M., Impact of biodiesel blending on diesel soot and the regeneration of particulate filters, Energy and Fuels, Vol.19 (2005), pp.1857-1864, DOI:10.1021/ef0500585.

Bockhorn, H. (ed.), Soot formation in combustion - Mechanisms and Models (1994), p.177 and p.427, Springer-Verlag.

Dec, J., A conceptual model of DI diesel combustion based on laser-sheet imaging, SAE Technical Paper 970873 (1997), DOI: $10.4271 / 970873$.

Hattori, Y. and Aizawa, T., Time-resolved sampling and transmission electron microscopy (TEM) of soot particles in diesel spray flame, Proceedings of the 25th Internal Combustion Engine Symposium No.19 (2014) (in Japanese).

Harada, T., Koga, N., Aizawa, T., Adachi, T. and Kusaka, J., Diesel spray flame using $50 \mu \mathrm{m}$ thin-wire type-R thermocouple, Proceedings of the 24th Internal Combustion Engine Symposium No.51 (2013).

Heywood, J. B. (ed.), Internal combustion engine fundamentals, (1988), p.631, pp.645-646, McGraw-Hill.

Ishiguro, T., Takatori, Y. and Akihama, K., Microstructure of diesel soot particles probed by electron microscopy: First observation of inner core and outer shell, Combustion and Flame, Vol.108 (1997), pp.231-234, DOI: 10.1016/S0010-2180(96)00206-4.

Ito, T., Hosaka, T., Ueda, M., Senda, J. and Fujimoto, H., Detailed kinetic modeling and laser diagnostics of soot formation process in diesel jet flame, SAE Technical Paper 2004-01-1398 (2004), DOI:10.4271/2004-01-1398.

Kondo, K., Aizawa, T., Kook, S. and Pickett, L., Uncertainty in sampling and TEM analysis of soot particles in diesel spray flame, SAE Technical Paper 2013-01-0908 (2013), doi:10.4271/2013-01-0908.

Kook, S. and Pickett, L. M., Soot volume fraction and morphology of conventional and surrogate jet fuel sprays at 1000-K and 6.7-MPa ambient conditions, Proceedings of Combustion Institute, Vol.33, No.2 (2011), pp.2911-2918, DOI:10.1016/j.proci.2010.05.073.

Kook, S., Zhang, R., Szeto, K., Pickett, L. and Aizawa, T., In-flame soot sampling and particle analysis in a diesel engine, SAE International Journal of Fuels Lubricants, Vol.6, No.1 (2013), pp.80-97, DOI:10.4271/2013-01-0912.

Kosaka, H., Nishigaki, T., Kamimoto, T. and Harada, S., A study on soot formation and oxidation in an unsteady spray flame via laser induced incandescence and scattering techniques, SAE Technical Paper 952451 (1995), DOI:10.4271/952451.

Kosaka, H., Aizawa, T. and Kamimoto, T., Two-dimensional imaging of ignition and soot formation processes in a diesel flame, International Journal of Engine Research, Vol.6, No.1 (2005), pp.21-42, DOI:10.1243/146808705X7347.

Kuribayashi, M., Ishizuka, Y. and Aizawa, T., Sizing of soot particles in diesel spray flame -A qualitative comparison between TEM analysis and LII/scattering laser measurements, SAE International Journal of Fuels and Lubricants, Vol.6, No..3 (2013), pp.641-650, DOI:10.4271/2013-01-2576.

Kuribayashi, M., Mizutani, Y., Ishizuka, Y., Taki, N. and Aizawa T., Effects of ambient oxygen concentration on soot processes in diesel spray flame - A qualitative comparison between TEM analysis and LII/Scattering laser measurements, SAE International Journal of Fuels and Lubricants, Vol.7, No.3 (2014), pp.693-703, DOI:10.4271/2014-01-2642.

Lee, K. O., Megaridis, C. M., Zelepouga, S., Saveliev, A. V. and Kennedy, L. A., Soot formation effects of oxygen concentration in the oxidizer stream of laminar coannular nonpremixed methane/air flames, Combustion and Flame, Vol.121 (2000), pp.323-333, DOI:10.1016/S0010-2180(99)00131-5.

Lee, K. O., Cole, R., Sekar, R., Choi, M. Y., Kang, J. S., Bae, C. S. and Shin, H. D., Morphological investigation of the microstructure, dimensions, and fractal geometry of diesel particulates, Proceedings of Combustion Institute, Vol.29 (2002), pp.647-653, DOI:10.1016/S1540-7489(02)80083-9.

Li, Z., Song, C., Song, J., Lv, G., Dong, S. and Zhao, Z., Evolution of the nanostructure, fractal dimension and size of in-cylinder soot during diesel combustion process, Combustion and Flame, Vol.158, No.8 (2011), pp.1624-1630, DOI:10.1016/j.combustflame.2010.12.006.

Matsushita, M., Physics of fractals (I) -An introduction-, Shokabo (2002), pp.130-140 (in Japanese). 
Megaridis, C. M. and Dobbins, R. A., Morphological description of flame-generated materials, Combustion Science and Technology, Vol.71 (1990), pp.95-109, DOI:10.1080/00102209008951626.

Nerva, J., Yamaguchi, T., Iguma, H., Nishigai, H., Kondo, K., Takano, S., Aizawa, T., Genzale, C. L. and Pickett, L. M., Transmission electron microscopy of soot particles sampled directly from a biodiesel spray flame, SAE Technical Paper 2011-01-2046 (2011), DOI:10.4271/2011-01-2046.

Palotas, A. B., Rainey, L. C., Feldermann, C. J., Sarofim, A. F. and Vander Sande, J. B., Soot morphology: An application of image analysis in high-resolution transmission electron microscopy, Microscopy Research and Technique, Vol.33 (1996), pp.266-278, DOI:10.1002/(SICI)1097-0029(19960215)33:3<266::AID-JEMT4>3.0.CO;2-O.

Schaefer, D.W., Fractal models and the structure of materials, MRS Bulletin, Vol.13, No.2 (1988), pp.22-27, DOI: dx.doi.org/10.1557/S088376940006632X.

Song, J., Alam, M. and Boehman, A.L., Characterization of diesel and biodiesel soot, Preprints of Papers -American Chemical Socienty, Devision of Fuel Chemistry, Vol. 49, No.2 (2004), pp.767-769.

Song, J., Alam, M., Boehman, A. L. and Kim, U., Examination of the oxidation behavior of biodiesel soot, Combustion and Flame, Vol.146 (2006), pp.589-604, DOI:10.1016/j.combustflame.2006.06.010.

Vander Wal, R. L., Yezerets, A., Currier, N. W., Kim, D. H. and Wang, C. M., HRTEM Study of diesel soot collected from diesel particulate filters, Carbon,Vol.45 (2007), pp.70-77, DOI:10.1016/j.carbon.2006.08.005.

Vander Wal, R. L. and Mueller, C. J., Initial investigation of effects of fuel oxygenation on nanostructure of soot from a direct-injection diesel engine, Energy and Fuels, Vol.20 (2006), pp.2364-2369, DOI:10.1021/ef060201+Publication Date (Web): September 14, 2006.

Yamaguchi, T., Iguma, H., Nishigai, H., Kondo K., Takano, S., Aizawa, T., Nerva, J., Genzale, C.L. and Pickett, L.M., High-resolution transmission electron microscopy of soot particles in diesel spray flame (2) (Properties of soot sampled in bio-diesel spray flame), Proceedings of the 21th Internal Combustion Engine Symposium (2010), No. B7-3 (in Japanese).

Yamaguchi, T., Kondo, K., Nishigai, H., Takano, S. and Aizawa, T., Direct sampling, TEM analysis and optical measurement of soot particles at different axial locations in a transient spray flame, SAE International Journal of Fuels Lubricants, Vol.5, No.1 (2012), pp.316-328, DOI:10.4271/2011-01-2051.

Zhang, R. and Kook, S., Structural evolution of soot particles during diesel combustion in a single-cylinder light-duty engine, Environmental Science and Technology (2014).

Zhu, J., Lee, K. O., Yozgatligil, A. and Choi, M. Y., Effects of engine operating conditions on morphology, microstructure, and fractal geometry of light-duty diesel engine particulates, Proceedings Combustion Institute, Vol.30 (2005), pp.2781-2789, DOI:10.1016/j.proci.2004.08.232. 